\title{
PROVISIONS ON DEATH CRIMINAL THREATS IN NARCOTIC LAW IN THE PHILOSOPHICAL BASIS PERSPECTIVE
}

\author{
Faissal Malik \\ Fakultas Hukum, Universitas Khairun Ternate \\ Email : faissalmalik10@gmail.com
}

\begin{abstract}
The threat of capital punishment is seen as an appropriate type of crime threatened against narcotics offenders with the qualifications of producers and dealers, because narcotics is a serious crime and the nature of the offenders who have a network to produce and circulate narcotics for business or economic purposes only so that their actions can cause great danger or have a profound effect on human life and national life in the political, economic, social, cultural and national defense sectors. In the end the deterrent effect with a very severe sentence, including the threat of capital punishment, became the target to achieve the goal of enacting Law Number 35 Year 2009 on Narcotics in addition to providing narcotics for health needs and scientific development, also intended to reduce the quantity of perpetrators of abuse and circulation dark narcotics. Although it is realized that with the enactment of this law, the number of drug abuse and distribution by the perpetrators does not deter and can educate producers and distributors of the sentences not proportional to their actions compared to the consequences suffered by victims. In other words, the target of the regulation of death penalty in this law is not only for death row inmates, but also for potential perpetrators who have not yet been sentenced to death. Therefore, the threat of capital punishment aims to suppress the high crime rate, which in the end the community becomes orderly, peaceful and safe.
\end{abstract}

Keywords: narcotics, capital punishment, punishment

\section{Introduction}

The development of illicit trafficking and the abuse of narcotics and other addictive substances has become an important topic. This has become a serious problem and has reached a situation of concern because it occurs within the national sphere and has crossed national borders when viewed from convergence and technology used (Hamzah and Siti Rahayu, 1983). Illicit trafficking and narcotics abuse have expanded beyond the boundaries of social strata, age, sex. Urban is no longer a priority of dealers but has penetrated to the countryside and transcended national borders which consequently adversely affects individuals, communities, and countries (Hidayat \& Hasan Asy "ari, 2013). Such a situation puts the trafficking and abuse of narcotics into a common enemy of the nations of the world because their effects are very damaging to mankind, especially the younger generation. That is what led to a mutual agreement from countries in the world to combat narcotics and other addictive 
substances that are illegally circulated.

Meanwhile, the 2008 data, it can be stated that the number of narcotics abusers has reached 1.5\% of the Indonesian population or around 3.1 million to 3.6 million people. Of the number of abusers, $26 \%$ try to use it, $27 \%$ regularly use $40 \%$ non-injection addicts and $7 \%$ injecting addicts. Narcotics abuse in non-student groups $(40 \%)$. Whereas according to male gender ( $88 \%)$ is much greater than in women $(12 \%)$. The estimated loss of economic costs due to narcotics crime in 2008 was around 37\% higher than in 2004, with a total cost loss of around Rp. 32.4 trillion (2008) consisting of Rp. 26.5 trillion individual (private) losses and Rp. 5.9 trillion is social costs. Most of the private costs (58\%) are for narcotics consumption costs, while the majority of social costs $(60 \%)$ are allocated for loss due to narcotics (premature dealth). The results of the University of Indonesia's Research Institute projections in collaboration with the National Narcotics Agency (BNN) show economic losses due to narcotics abuse increased from $\mathrm{Rp}$. 32.4 trillion in 2008 to Rp. 57 trillion in 2013. University of Indonesia (UI) Research Data in collaboration with the National Narcotics Agency (BNN) mentioned above, shows that the actions of producers and dealers in illegally producing and distributing narcotics in their networks to be traded to users or users continue to increase. This condition certainly threatens and endangers the lives of the people, nation and state.
Indonesia is not only used as a transit point in the trafficking and illicit trafficking of narcotics, but has become a marketing / destination place, and has become a place to produce narcotics by narcotics offenders. This, due to several factors, including:

1. Indonesia's very strategic position in the cross position of two continents and two oceans (Asian Continent and Australian Continent, and Indian Ocean and Pacific Ocean), making it easier for narcotics illicit trafficking syndicates to smuggle narcotics;

2. A large population is very potential to be a market for narcotics circulation. For narcotics distribution networks in Asian countries, Indonesia is considered as the most prospective commercial marketstate for international syndicates operating in developing countries;

3. State territory consisting of islands causes difficulties for law enforcement officials to conduct surveillance; and

4. The effect of globalization, highly developed transportation flows can support the illicit trafficking of narcotics (Bahtiar, 2002).

From these factors, Indonesia is considered a safe place to carry out trafficking / illicit trafficking of narcotics and narcotics abuse. This is at least very reasonable, in line with the opinion of Sumirat Dwiyanto (2015), saying that the rush of narcotics dealers into Indonesian territory was recorded at a total of 48 trillion. Transactions with this figure 
are fantastic. When compared with the total transactions that occurred in ASEAN amounted to 160 trillion. The narcotics dealers come from Indonesia, Malaysia, Australia, Iran, France, Taiwan, Nigeria and others. The producers and dealers certainly get huge profits with a total circulation of $30 \%$ in Indonesia. In contrast to Sumirat, Asep Iwan Iriawan, argues that the narcotics dealers think that the sentence in Indonesia is a light sentence and for life, the death sentence in Indonesia is only on paper. The death penalty only applies to terrorist crimes and premeditated murder. Even in prison, mafia who are caught and sentenced to death can still control and run the narcotics business and other addictive substances. There are no executions in Indonesia. That is the thought of the narcotics dealer regarding the applicable law in Indonesia. According to him, the confession of one of the narcotics dealers who was caught finally collaborated with law enforcement that in Indonesia can do money laundering in the form of donations to certain institutions or activists campaigning against the death penalty to disrupt and influence government policy (2015).

The rise of illegal production and distribution of narcotics in the community and the magnitude of the impact of losses, both economic losses and social losses incurred, opened the awareness of various groups to declare war on narcotics and other illegal drugs. This condition must be taken seriously by the government so as not to cause social effects in the community. One form of responding to the increasingly widespread illicit trafficking and abuse of narcotics is by reviewing the laws and regulations so that they can adjust to the widespread and systematic distribution of illicit drugs and the use of narcotics at both the national and international levels. This research will discuss the Provisions on Death Criminal Threats in Narcotic Law in The Philosophical Base Perspective.

\section{Discussion \\ Definition and Definition of Narcotics}

Etymologically narcotics come from English "narcose" or "narcosis" which means to sleep and sedate (Sadili, 1996). Narcotics come from Greek, which is "narcotic" which means anesthetized so that it does not feel anything. In terminology, in the Big Indonesian Dictionary, (KBBI) defines narcotics as drugs that can calm nerves, relieve pain, cause drowsiness, or stimulate (Moelyono, 1988).

Smith Kline and French Clinical, as quoted by Mardani, define narcotics as follows:Narcotic are drugs which produce incencibility or stuper due to their depressant effect on the central system. Included in this definition tire opium, opium derivatives (morphine, codeine, heroin) and synthetic opiates (meperidei, methadone) (Mardani, 2008). According to William Benton: Narcotic is general term for the substance that produces lethargy or super or the relief of pain. According to Soedjono Dirdjosisworo: Narcotics are materials which mainly have the effect of sedation or can reduce consciousness (Dirdjosisworo, 1997). 
The definition and expert opinion regarding the definition of narcotics as stated above, show that narcotics are substances or substances that can function as drugs that can affect consciousness, but if misused can damage physically (such as addiction) and mental (loss of consciousness, behavior, encouragement desire) the user, both natural ingredients and synthesis (the results of laboratory processing).

\section{The Impact of Drug Abuse From the Health Dimension}

Narcotics abuse damages / destroys human health both physically and spiritually / mentally and emotionally. Because it can damage the central nervous system in the brain, other organs such as liver, heart, kidneys, intestines and other complications. In addition it also causes disturbances to the normal development of adolescents, memory, feelings, perception and self control. Narcotics abuse can also damage the reproductive system, which is a decrease in the hormone testosterone, chromosomal damage, sex disorders, miscarriages and others. Likewise for the spread of AIDS through narcotics use using shared needles, if the person concerned has AIDS (Bachtiar, 2002). In the United States every year, thousands of narcotics addicts die from over dosage. Many more died from AIDS. According to the United Nations, about $22 \%$ of the population who are HIV positive in the world are narcotics users who inject themselves with contaminated needles. It was further explained that the rampant use of narcotics, especially by the younger generation in the past 2-3 years, poses an entirely new problem in lung disease, especially lower respiratory tract infections. Drug addicts with an injection have a risk of death 7 times higher than the general population in the same age group. Pneumonia in narcotics users is 10 times more common than pneumonia in the general population.

\section{Philosophical Basis for the Death Penalty Threat in Narcotics Law}

Philosophical foundation or philosophical norms of law enforcement, meaning that legal norms are in accordance with legal ideals as the highest positive value. This philosophical foundation is Pancasila values and constitutional values. The values of Pancasila include, the values of God, humanity, unity, democracy and social justice. While the constitutional values are values of justice, legal benefits and legal certainty, and other values. This foundation is where the legal norms depend on it and has implications for the legal norms under which they should not contradict these values (Lailam, 2017). The basic values of Pancasila in the form of the values of God, humanity, unity / nationality, people, and social justice are a unified whole and cannot stand alone. The five values contain values in the field of law (legal value), the legal value which is the crystallization of the five Pancasila values is manifested in the legal ideal (rechtsidee). The basic values of Pancasila as a legal ideal are the guiding stars, this position requires the formation of national law to reach the ideas in Pancasila. 
Harjono's view, that Pancasila as the basis of the state (groudslag) has different gradations from the Pancasila listed in the Preamble of the 1945 Constitution, Pancasila as the basis of the state is a philosophy and basic thinking, general and inter-precepts with subsequent precepts are separate, whereas Pancaila listed in The opening of the 1945 Constitution shows that the five precepts do not stand alone in organizing the state (Harjono, 2008).

According to Hamit S. Attamimi, the legal ideal serves as a guiding star for the achievement of the ideals of the community, although it is an unlikely end point, the legal ideal provides benefits because it contains two sides: (i) the positive legal ideals applicable can be tested; and (ii) towards the ideals of the law, positive law as an effort towards something fair with coercive sanctions can be directed. In contrast to Attamimi, Koesnoe, as quoted by Ni'matul Huda, said that the ideal of the law is the legal value that has been mixed in unity with other values, which also shows the extent of the phenomenon of power integrated with it. The legal ideal covers the formal aspect, namely as a container of legal values that have been worked out by taking into account the nature of the reality surrounding the group concerned. The meteril aspect or substance of the legal ideal is as a legal value that has been mixed in a unity with the values of other value categories including the phenomenon of power, according to the cultural taste of the community concerned (Ni'matul Huda, 2008).
In relation to basic norms and rechtsidee, the roles and functions of Pancasila in the formation of national law are:

a. The ideals of the Pancasila law function as regulative and constitutive benchmarks. Without the legal ideal, the resulting legal product will lose its meaning, in this case Pancasila will become the standard of evaluation in the legislation in Indonesia;

b. The ideals of the Pancasila law are factors that motivate and guide the guiding principle in the administration of law;

c. The ideals of the Pancasila Law determine the problems, methods and explanations that are considered relevant to study so that they are the key to the formation of law by legal institutions;

d. As a norm of criticism (evaluation rules) in facing challenges related to law enforcement, because it functions to determine the limits of justification, benchmarks about moral ethics, honor and dignity of the nation;

e. As a guiding star for the achievement of the ideals of society.

Thus, the accommodation of philosophical values in the formation of rules is highly dependent on the level, knowledge, awareness and appreciation of these values by the actors forming the rules. If the legislators are not able to understand this, it is clear that this condition will have implications for the value gap with the legal norms created (conflicting norms with 
values). In a statutory regulation, the philosophical basis contained in the considerations / basis considers the formation of the law, but not only that the philosophical basis also crystallizes in every detail of the Article or paragraph in the regulation, meaning that each Article must also contain values philosophy. The philosophical foundation, Law No. 35 of 2009 concerning Narcotics, states that the law was formed due to several philosophical considerations, including: (i) "that to realize a prosperous, just, and prosperous Indonesian society that is equally material and spiritual based on Pancasila and the Constitution RI 1945, the quality of Indonesia's human resources as one of the national development capital needs to be maintained and improved continuously, including the degree of health "(ii)" that in order to improve the health status of Indonesian human resources in order to realize the people's welfare it is necessary to improve in the medical field and health services, among others by seeking the availability of certain types of narcotics which are very much needed as medicines and to prevent and eradicate the dangers of abuse and illicit trafficking of narcotics and narcotics precursors "(iii) that narcotics on one side are drugs or substances that have benefits. in the field of medicine or health services and the development of science and the other side can also cause a very detrimental dependence if misused or used without strict and careful control and supervision "(iv)" that importing, exporting, producing, planting, storing, distributing, distributing , and / or using narcotics without strict control and supervision and in violation of the laws and regulations constitutes a narcotics crime because it is very detrimental and constitutes a great danger to the lives of people, society, nation, and state as well as Indonesia's national security; (v) "that the narcotics crime has been transnational in nature which is carried out using a high modus operandi, sophisticated technology is supported by a wide network of organizations and has caused many victims, especially in the young generation of the nation which is very dangerous to the lives of the people, nation and state ". This explanation, at least, illustrates that in the process of substance formation Article or paragraph in Law Number 35 Year 2009 concerning Narcotics must refer to the basic spirit or ideas in the considerations as a philosophical basis that has been normalized in the form of criminal sanctions as an instrument to provide protection for individual legal interests, society and country.

Criminal law is a law that is relatively close to the public. The acceptance is marked by how responsive the community is to various types of criminal acts that occur around them. It is familiar to a certain community to take preventative actions for the creation of a safe and conducive environment. The patrolling activity, for example, is one example where people think of the best ways to prevent criminal acts in their environment. On the other hand, people are often reactive by wanting certain types of crimes to be handed 
down to perpetrators of crime, especially if the victim is a member of the community. The dimensions of crime prevention and the imposition of sanctions / sentences described above are part of the concerns of criminal law as a scientific branch (Zulva et al, 2017). However, it must also be realized that the public also does not have the right ability to understand the type and number of criminal acts that occur around it. Likewise with the type of sanctions that are appropriate to be threatened and imposed on the perpetrators.

Once the importance of the norm of sanctions in the penal system is to establish a sanction, its existence provides a direction for consideration as to what should be used as a sanction in a criminal act to enforce the norm. On the other hand, punishment itself is the most complex process in the criminal justice system because it involves many different people and institutions. Criminalization can be interpreted as a stage of determining sanctions and providing sanctions in criminal law. Sudarto, argues that the granting of criminal sanctions in abscracto is to establish a system of criminal law sanctions concerning the formation of the law. Whereas the granting of criminal acts in concreto concerns various bodies which all support and implement the system of criminal law sanctions (Sudarto, 1996). In contrast to Sudarto, G.P Hoefnagels, argues that criminal sanctions in criminal law are all reactions to violations of the law determined by the law starting from the detention of the suspect and the prosecution of the defendant to the conviction by the judge. Further explained that the criminal as a time process in which the whole process is considered as a criminal (Barkatullah, 2005). Based on the opinion of Sudarto and Hoefnagels above, it can be interpreted that the determination of sanctions in criminal law is a set of policies that are in a system. As a system, each stage of criminal giving can stand alone, but are interrelated and cannot even be separated at all.

In connection with efforts to justify the existence of criminal sanctions, Muladi argues that the norm of the death penalty is always associated with criminal objectives, ranging from retributive theory or absolute theory, then utilitarian theory or relative theory to combined theory. All these theories in general are still debated by legal experts. Nevertheless the determination of criminal sanctions is largely determined by the type of criminal act committed. He further explained that public opinion is often the deciding factor of a decision whether a country will retain, abolish or reinstate capital punishment. "Penalty policy" measures without public support will undermine confidence in the law and are likely to lead to personal retaliation and be considered antidemocratic if the legislator ignores strong public sentiment. Such legal policies are often inseparable from political ideologies and the sources from which trust in legal authority originates. In Middle Eastern and North African countries, for example, the perseverance to maintain the threat of capital punishment is a result of the clear 
word of his religious doctrine (Islam). Conversely in democracies where law is based on the mandate given by its elected representatives, it is clearly an obligation for the legislature to follow public opinion.

Regarding the regulation of the norm of the death penalty in Law Number 35 of 2009 concerning Narcotics, starting with the idea to renew Law Number 22 of 1997 concerning Narcotics which is getting stronger. This is marked by the MPR having given a recommendation to the President to reform Law Number 22 of 1997 on Narcotics through MPR Decree No.VI/MPR/2002 regarding Recommendations on the Report on the Implementation of the Decision on the Implementation of the People's Consultative Assembly by the President, DPA, DPR, BPK, and MA. In this MPR TAP, the MPR views the narcotics problem from three sides, namely those related to morality, declining morality, increasing HIV / AIDS sufferers, and increasing public unrest. Therefore the recommended steps to be taken by the government are:

a. Increase the budget in the context of development in the field of Religion;

b. Take decisive actions in accordance with applicable laws against producers, dealers, and users and take effective, anticipatory and educative coordination steps with related parties and the public;

Together with the DPR, revise Law Number 22 of 1997 concerning Narcotics and Law Number 5 of 1997 concerning Psychotropics (RI MPR Decree No.VI/MPR/2002).

Furthermore, the Government and the Parliament of the Republic of Indonesia then ratified and promulgated Law Number 35 Year 2009 concerning Narcotics. One of the fundamental changes in this law is the improvement of the status of the National Narcotics Agency (BNN) as a Non-Ministry Government Institution which is given the authority to investigate and investigate narcotics and narcotics precursors. In Law Number 35 Year 2009 concerning Narcotics, the death penalty is regulated as part of efforts to put a deterrent effect on the traffickers and illicit abuse of narcotics and narcotics precursors, then criminal prosecution especially the inclusion of the death penalty because narcotics circulation will pose a greater danger. for life which will ultimately weaken national resilience (Anggara et al, 2017). In addition, related to the idea of the inclusion of the threat of capital punishment which is threatened against producers and dealers in narcotics crime, the Government has affirmed its opinion that the threat of capital punishment is needed because it is considered a crime of humanity aimed at wiping out humanity slowly but surely, because of the full potential of reason and human minds are massively damaged for personal and group interests (Decision of the Constitutional Court, Case Number 2 / PUU-V / 2007). Then, the Government illustrates that criminal acts of narcotics, humans are made like an undead that no longer has the 
potential to develop civilization and culture, but continue to behave in a way that destroys the fabric of life. Because of that, narcotics crime will always be threatened with serious crime including death penalty. In addition to the views used by the Government, this law intends to frighten people from committing criminal acts, either frightening the people (generale preventive) or scaring certain people who have committed criminal acts so that in the future they will not commit more criminal acts (special preventive). In addition, this law also aims to educate or improve people who have committed criminal acts so that people become good at character, so that it benefits the community (Prodjodikoro, 1989).

The threat of capital punishment is seen as an appropriate type of crime threatened against narcotics offenders with the qualifications of producers and dealers, because narcotics is a serious crime and the nature of the offenders who have a network to produce and distribute narcotics for business or economic purposes only so that their actions can cause great danger or have a profound effect on human life and national life in the political, economic, social, cultural and national resilience fields (Rahayu, 1983). In the end the deterrent effect with a very severe sentence, including the threat of capital punishment, became the target to achieve the goal of enacting Law Number 35 Year 2009 on Narcotics in addition to providing narcotics for health needs and scientific development, also intended to reduce the quantity of perpetrators of abuse and circulation dark narcotics. Although it is realized that with the enactment of this law, the number of drug abuse and distribution by the perpetrators does not deter and can educate producers and distributors of the sentences not proportional to their actions compared to the consequences suffered by victims. In other words, the target of the regulation of death penalty in this law is not only for death row inmates, but also for potential perpetrators who have not yet been sentenced to death. Therefore, the threat of capital punishment aims to suppress the high crime rate, which in the end the community becomes orderly, peaceful and safe.

In line with the basic ideas developed by lawmakers and the views of legal experts in setting norms of the death penalty threatened with perpetrators with qualifications as producers and dealers as stated above, Muladi believes that the reasons for the use of norms of the death penalty against perpetrators (producers and dealers) in narcotics crimes, as follows: First, narcotics crimes, particularly organized producers and dealers are crimes whose effects are "anthropocentric" (can destroy the younger generation) and tend to lead to transnational organized crimes (transnational organized crimes) ) that endangers national and international security. Even narcotics crimes are "predicate crimes" (early crimes) against money laundering crimes, the results of which are used to develop other crimes such as terrorism; second, the character of narcotics crime is a very serious 
crime (the most serious crimes), considering narcotics crime as a crime that causes severe and extreme consequences including death; Third, narcotics crime develops rapidly considering various factors of criminogen that have various potentials, such as human security, such as: high social mobility due to globalization, Indonesia has a large democratic potential as a narcotics consumer, geographical location as an archipelagic nation vulnerable to infiltration especially organized transnational crime (Muladi, 2013).

\section{Conclusion}

Philosophical foundation or philosophical norms of law enforcement, meaning that legal norms are in accordance with legal ideals as the highest positive value. This philosophical foundation is Pancasila values and constitutional values. The values of Pancasila include, the values of God, humanity, unity, democracy and social justice. While the constitutional values are values of justice, legal benefits and legal certainty, and other values. This foundation is the place where the legal norms depend on it and have implications for the legal norms under which they are not allowed to contradict these values. The threat of capital punishment is seen as an appropriate type of crime threatened against narcotics offenders with the qualifications of producers and dealers, because narcotics is a serious crime and the nature of the offenders who have a network to produce and circulate narcotics for business or economic purposes only so that their actions can cause great danger or have a profound effect on human life and national life in the political, economic, social, cultural and national defense sectors. In the end the deterrent effect with a very severe sentence, including the threat of capital punishment, became the target to achieve the goal of enacting Law Number 35 Year 2009 on Narcotics in addition to providing narcotics for health needs and scientific development, also intended to reduce the quantity of perpetrators of abuse and circulation dark narcotics. Although it is realized that with the enactment of this law, the number of drug abuse and distribution by the perpetrators does not deter and can educate producers and distributors of the sentences not proportional to their actions compared to the consequences suffered by victims. In other words, the target of the regulation of death penalty in this law is not only for death row inmates, but also for potential perpetrators who have not yet been sentenced to death. Therefore, the threat of capital punishment aims to suppress the high crime rate, which in the end the community becomes orderly, peaceful and safe.

\section{References}

Andi Hamzah dan Siti Rahayu, 1983, Suatu Tinjauan Ringkas Sistem Pemidanaan di Indonesia, Jakarta, Akademika Pressindo.

Andi Hamzah dan Siti Rahayu, 1983, Suatu Tinjauan Ringkas Sistem Pemidanaan di Indonesia, Jakarta, Akademika Pressindo. 
Anggara dkk, (Tim Peniliti ICJR), 2017, Politik Kebijakan

Hukuman Mati Di Indonesia

Dari Masa Ke Masa, Institute

For Criminal Justice Reform.

Anton M. Moelyono, 1988, Kamus Besar Bahasa Indonesia, Jakarta, Balai Pustaka.

Da'i Bachtiar, 2002, "Kebijakan dan Strategi Badan Narkotika Nasional Dalam Pencegahan dan Pemberantasan Penyalahgunaan dan Peredaran Gelap Narkotika dan Psikotropika" Makalah, Disampaikan Dalam Seminar Nasional BNN Tanggal 16 April, Jakarta.

Dai Bahtiar, 2002, "Kebijakan dan Strategi Badan Narkotika Nasional Dalam Pencegahan dan Pemberantasan Penyalahgunaan dan Peredaran Gelap Narkotika dan Psikotropika", Makalah Disampaikan Dalam Seminar Nasional BNN 16 April, di Jakarta.

Eva Achjani Zulva dkk, 2017, Perkembangan Sistem Pemidanaan dan Sistem Pemasyarakatan, Rajawali Press, Depok.

Harjono, 2008, Konstitusi Sebagai Rumah Bangsa, Sekjend dan Kepanitraan MKRI, Jakarta. Hoefnagels, Dalam Teguh Prasetyo, dan Abdul Halim Barkatullah, 2005, Politik Hukum Pidana, Kajian Kebijakan Kriminalisasi dan Dekriminalisasi, Pustaka Pelajar, Yogyakarta.

Jhon M. Elthols dan Hasan Sadili, 1996, Kamus Inggris
Indonesia, Jakarta, Gramedia Cet.XXIII.

Kabag Humas BNN Sumirat Dwiyanto pada 19 Januari 2015 dalam Acara Primetime Talk di Berita satu TV Ketetapan MPR RI No.VI/MPR/2002 tentang Rekomendasi atas Laporan Pelaksanaan Putusan MPR oleh Presiden, DPA, DPR, BPK, dan MA.

Mardani, 2008, Bunga Rampai Hukum Aktual, Jakarta, Ghalia Indonesia.

Muladi, 2013, Bahan Kuliah HAM, Politik Hukum Dalam Pengaturan dan Pelaksanaan Pidana Mati di Indonesia, Khususnya Dalam Tindak Pidana Narkotika.

Muladi, 2017, Penyampaian Materi Pada Seminar Tentang "Politik Kebijakan Hukuman Mati Di Indonesia Dari Masa Ke Masa" Pada Hari Selasa Tanggal 19 Desember 2017 di Hotel Aryaduta Di Jakarta Ni'matul Huda, 2008, UUD 1945 dan Gagasan Amandemen Ulang, Rajawali Press, Jakarta.

Pendapat Asep Iriawan, "Wawancara

Khusus Tentang Hukuman

Mati Bahaya Peredaran

Narkotika" Di Acara

Primetime Talk Di Berita Satu TV Tanggal 19 Januari 2015

Putusan Mahkamah Konstitusi, Perkara Nomor 2/PUU$\mathrm{V} / 2007$.

Soedjono Dirdjosisworo, 1997, Patologi Sosial, Bandung, Alumni.

Syamsul Hidayat \& Hasan Asy"ari, 2013, “Kontroversi Penerapan 
Pidana Mati Terhadap Tindak

Pidana Narkoba", Dalam Jurnal IUS Kajian Hukum dan Keadilan, Vol I Nomor 3 Desember.

Tanto Lailam, 2017, Teori dan Hukum Perundang-Undangan,

Pustaka Pelajar, Yogyakarta.

Wirjono Prodjodikoro, 1989, Asas-

Asas Hukum Pidana Di

Indonesia, Bandung, Eresco. 